\title{
A VERGONHA QUE NÃO NOS PERTENCE
}

Gustavo Jugend ${ }^{1}$

\section{Resumo}

Buscamos no presente trabalho redeterminar a categoria filosófica de sujeito, levando em conta o evento de Auschwitz. Será apresentada, a partir da leitura de textos de Giorgio Agamben e de testemunhas dos campos de concentração nazistas, uma análise dos movimentos de subjetivação e dessubjetivação que constituem o indivíduo. Tal definição não pode vir desacompanhada de um estudo da linguagem e, por isso, este texto sempre manterá a possibilidade da fala em seu horizonte teórico. Está em pauta também a compreensão ou, pelo menos, a especulação de um novo discurso acerca da ética, uma vez que uma nova compreensão acerca do sujeito assim o demandaria.

Palavras-chave: Agamben; Auschwitz; Sujeito; Ética; Linguagem

\section{THE SHAME THAT DON'T BELONG TO US}

\begin{abstract}
We search in this present word to redetermine the philosophical category of subject, taking in consideration the Auschwitz event. It will be presented, from the study of Giorgio Agamben works and witnesses of Nazi concentration camps, an analysis of the subjectification and unsubjectification that constitutes the individual. Such definition cannot come unaccompanied of a language study and, because of that, this article will always keep the speech possibility in its theoretical horizon. It's also on the agenda the comprehension, or, at least, the speculation, of a new discourse about ethic, since a new comprehension of the subject would demand so.
\end{abstract}

Keywords: Agamben; Auschwitz; Subject; Ethics; Language. 
Eras a minha morte

a ti eu poderia reter quando tudo me desertava.

(Celan).

\section{Introdução}

Em 1989, Giorgio Agamben escreveu um prefácio para a edição francesa de uma de suas obras mais importantes. Intitulado Experimentum Linguae, o preâmbulo contém em destaque as seguintes palavras:

Mas o que pode ser uma tal experiência? Como é possível ter experiência não de um objeto, mas da própria linguagem? E, quanto à linguagem, não desta ou daquela proposição significante, mas do puro fato que se fale, de que haja linguagem?²

O que Agamben busca entender é a possibilidade de experiênciar a auto-referência da linguagem. As questões elencadas são tão significativas para o autor que no parágrafo seguinte ele sentencia: “[...] o âmbito que estas questões circunscrevem coincide sem resíduos para o meu trabalho." 3

Idas e vindas acerca de tais questões, Giorgio Agamben deriva seu pensamento até o ponto onde uma teoria da experiência da linguagem não é mais possível sem uma teoria do indivíduo: se por um lado - como aprendemos pela metafísica ocidental - todo discurso deve obrigatoriamente corresponder a um enunciador capaz de responder por tudo que se enuncia, por outro - como se afirma após a virada ontológica do século $X X$, ou pela psicanálise, por exemplo - existe uma lacuna entre a linguagem e seu enunciante. Assim, para se produzir uma ontologia da linguagem é necessário que se faça uma ontologia de seu portador.

Fato é que, se a linguagem pensada como um experimentum continua a ser protagonista no pensamento de Agamben, o filósofo leva a questão a uma ruptura com a idéia de que ela se dê como uma experiência auto-referente. Agora em dissincronia com a idéia kantiana de sujeito transcendental (com a idéia de que a relação entre experiência e linguagem seja uma relação entre categorias da razão pura) o autor passa a entender a relação aqui questionada não mais como uma simples passagem da Infância ${ }^{4}$ à História, mas a de uma determinação, não contemplada pela metafísica, entre signo e significado que não pode mais ser pensada como auto-referência. Tal determinação revela-se como 
uma diferença "resistente à significação" ${ }^{5}$ que oculta o significado na aparência do significante:

O fundamento desta ambigüidade do significar reside naquela fratura original da presença, que é inseparável da experiência ocidental do ser, e pela qual tudo aquilo que vem à presença, vem à presença como lugar de um diferimento e de uma exclusão, no sentido de que o seu manifestar-se é, ao mesmo tempo, um esconder-se, o seu estar presente, um faltar. ${ }^{6}$

É justamente sob a luz de que entre experiência e linguagem abre-se uma fratura insignificável que Agamben escreve O Que Resta de Auschwitz. O italiano busca no episódio do campo de concetração uma figura que permita uma análise mais detalhada de tal fratura. Nomeada por Muçulmano, a imagem oferecida pelo testemunho de quem habitou Auschwitz substitui a figura da linguagem como auto-referência por uma dessubjetivação na qual uma emoção libera e exibe justamente a fratura tematizada: trata-se da vergonha. Como veremos mais detalhadamente, dar à vergonha o papel de lugar da linguagem consigna o fundamento do homem não em vista de si mesmo, mas em vista de outrem; de tal sorte que podemos afirmar: para Agamben a questão pela experiência, linguagem e vida abandonou a exclusividade ontológica e se tornou, radicalmente, uma questão ética.

Mas só isso não basta. Para pensarmos uma ética fundada na vergonha sem recair no prognóstico que Nietzsche elaborou acerca da modernidade, deveremos pensá-la como uma vergonha expurgada de culpa. Nas palavras de Agamben:

Por isso na ética não há lugar para o arrependimento, por isso a única experiência ética (que, como tal, não pode ser nem uma tarefa nem uma decisão subjectiva) é ser a (sua própria) potência, existir a (sua própria) possibilidade; e expor em cada forma a própria amorfia e em cada acto a própria inactualidade. ${ }^{7}$

Nas páginas deste artigo tentaremos encontrar pistas de como Agamben pensa o sujeito e a linguagem, seus processos de subjetivação e dessubjetivação, ou seja, quais são os estatutos emotivo e racional daquele que fala; qual a possibilidade da fala, no que ela se funda; e, mais importante, quem fala, sujeito ou não-sujeito. Também é necessário incluir uma outra questão: se as ponderações apresentadas voltarem-se contra o pensamento da metafísica ocidental, faz-se necessário pensar uma nova ética?

5 LACAN, J. "L'instance de la lettre dans l'inconscient" In: Écrits: Paris, 1966. Apud. AGAMBEN, G. Estâncias - a palavra e o fantasma na cultura ocidental. Belo Horizonte: Editora UFMG, 2007, p. 221. 
Na primeira parte faremos uma leitura da alegoria ${ }^{8}$ proposta por Agamben no ensaio Genius do livro Profanações para tentarmos entender justamente os processos de subjetivação e dessubjetivação. Subsequentemente, manteremos nossos olhos voltados a O Que Resta de Auschwitz para, comparativamente com o trecho anterior, colocar lado a lado testemunhos de internos do campo. Desta forma tentaremos responder, pelo menos em parte, às perguntas que Giorgio Agamben faz a si mesmo e que, aqui, voltamos para nós.

\section{Genius Como Alegoria Do Pré-Individual}

\section{Genius: Subjetivação e Dessubjetivação}

$\mathrm{Na}$ busca de encontrar um fundamento para os processos de subjetivação e dessubjetivação da vida, Agamben abre o livro Profanações com o ensaio Genius. O filósofo busca na mitologia romana a figura alegórica de Genius, um anjo genial que delimita nossa vida, nos acompanhando desde o nascimento até a morte, momento no qual se estende frente a nós revelando sua face e, então, nos abandona.

A reflexão proposta por Agamben não se faz sem motivo. O autor demarca que nas celebrações ofertadas a Genius (que fundou a tradição ainda remanescente na forma das festas de aniversário) oferecia-se um banquete e cantavam-se canções em homenagem ao anjo do nascimento. Havia-se de manter Genius sempre favorável, haja vista que este é a “divinização da pessoa, o princípio que rege e exprime sua existência inteira". 9

A questão que surge aqui tenta alavancar que tipo de sujeito, e de pré-individual, aparece no interior da intimidade que se trava na relação entre Eu e esta parte não identificada da minha vida, este outro de mim mesmo. É preciso que tal busca tematize sempre os processos de subjetivação e dessubjetivação que propiciam os fenômenos inquiridos. É justamente a partir de uma exposição e de uma apreensão destes movimentos que poderemos obter um entendimento da proposta filosófica de Giorgio Agamben. A leitura do texto deverá nos trazer pistas para desvendar o caráter da vida que por Genius é originado e que a Genius retorna.

Genius, um anjo caprichoso cujas exigências não devem ser ignoradas. Como afirma Agamben:

É preciso ser condescendente com Genius e abandonar-se a ele; a Genius devemos conceder tudo o que nos pede, pois sua

Agamben rejeita a idéia de que suas ilustrações sejam metafóricas. Segundo ele seus recursos alegóricos não produzem uma transferência de significado. Antes, tais construções exibem um significado em toda sua possibilidade de conhecimento. Cf. AGAMBEN, Giorgio. What Is a Paradigm?. Disponivel em: http://www.egs.edu/faculty/giorgio-agamben/articles/ what-is-a-paradigm/. 
exigência é nossa exigência; sua felicidade, nossa felicidade. Mesmo que suas - nossas! - pretensões possam parecer inaceitáveis e caprichosas, convém aceitá-las sem discussão. ${ }^{10}$

Se Genius é a região que funda a felicidade por meio de uma exigência, não podemos deixar de notar que a tentativa de enganar Genius seria absolutamente nefasta; Genius funda vida e distancia o olhar da morte. De maneira bastante diversa da pensada pelos filósofos modernos ${ }^{11}$ (que pela primeira vez consideraram o processo de individuação que originaria o sujeito), os processos de subjetivação e dessubjetivação propostos aqui têm seu fundamento numa submissão da vida ao afeto genial, vontade que lhe põe em contato com o pré-individual. Genius é, como será explorado mais a frente, uma maneira de a existência manifestar-se ainda anterior a sua própria individuação: aquilo que traz a vida para perto do inaudito, das emoções, aquilo sobre o que não se tem domínio.

Se, como podemos notar, o sujeito está sempre se aproximando ou se desvencilhando dos opostos dicotômicos Eu e Genius, aparecem então de maneira mais clara os processos que Agamben está tentando descrever. Ora, uma vez que foi demarcado Genius como íntimo, impessoal, como sendo as vontades, e sendo Eu o seu oposto (público, pessoal, apaziguado), podemos usar as próprias palavras de Agamben para iluminar os processos que tentamos entender: "Devemos, pois olhar para o sujeito como para um campo de tensões, cujos pólos antitéticos são Genius e Eu"12.

A mera descrição do campo de tensões já não deve passar sem uma reflexão. Ao demarcar que os pólos limítrofes do sujeito são antitéticos, Agamben evita que seja possível confundir a formação do sujeito com uma relação onde as dicotomias apresentadas, a partir de um

Idem, p. 16.

A distinção entre o pensamento de Agamben e a filosofia moderna é necessária, uma vez que a ideia de subjetivação foi inaugurada pelos autores deste período. Uma das principais diferenças consiste no fato de a filosofia moderna não ter pensado o processo de dessubjetivação, de tal sorte que a figura do sujeito é fechada no interior de seu pensamento. Para Agamben, a subjetivação e a dessubjetivação são processos abertos. Cabe, a título de exemplo, lembrar o argumento cartesiano de sua Meditações Metafísicas conhecido como hipótese do gênio maligno. Se aqui (e acreditamos que a escolha da figura de Genius por Agamben não configura mera coincidência em relação ao argumento de Descartes) Genius atua em favor do índividuo garantindo que ele possa experimentar subjetivação e dessubjetivação, em Descartes o gênio maligno é um inimigo a ser afastado pelo sujeito de maneira que este não possa abrir mão de seu precioso cogito: "Suporei, pois, que há não um verdadeiro Deus, mas certo gênio maligno, não menos ardiloso e enganador do que poderoso, que empregou toda a sua indústria em enganar-me. Pensarei que o céu, o ar, a terra, as cores, as figuras, os sons e todas as coisas exteriores que vemos são apenas ilusões e enganos de que ele se serve para surpreender minha credulidade. Considerar-me-ei a mim mesmo absolutamente desprovido de mãos, de olhos, de carne, de sangue, desprovido de quaisquer sentidos, mas dotado da falsa crença de ter todas essas coisas. [...]. Eis por que cuidarei zelosamente de não receber em minha crença nenhuma falsidade, e prepararei tão bem meu espírito a todos os ardis desse grande enganador que, por poderoso e ardiloso que seja, nunca poderá impor-me algo." DESCARTES, R. Meditações. In: Col. Os Pensadores, volume Descartes. São Paulo: Abril Cultural, 1973, pp. 96, 97.

AGAMBEN, Profanações. São Paulo: Boitempo, 2007, p. 18. 
processo dialético, venham se chocar para dar origem a um ser sintático e fechado. Não se trata disso. Antes podemos auspiciar precisamente uma polarização que traz o sujeito mais para perto do pré-individual ou, ao contrário, repele este, tornando-se assim indivíduo. A imagem formulada pelo autor pode valer de boa ilustração:

O campo é atravessado por duas forças conjugadas, porém opostas; uma que vai do individual na direção do impessoal, e outra que vai do impessoal para o individual. As duas forças convivem, entrecruzam-se, separam-se, mas não podem nem se emancipar integralmente uma da outra nem se identificar perfeitamente. $^{13}$

O processo que vai do individual na direção do impessoal e, portanto, na direção de Genius, é o processo da dessubjetivação. O processo inverso, do impessoal para o individual, para perto do Eu, é a subjetivação. Se, como afirma Agamben, essas duas forças jamais se emancipam, fica impugnada a possibilidade da existência de um ser-sujeito que venha a abolir completamente seu pré-individual; assim como também somente a partir da retomada da questão em O que é um dispositivo ${ }^{14}$ pode-se conjecturar a possibilidade de existência de um ser-dessubjetivado incapaz de uma nova subjetivação (mas não ainda se partirmos da leitura de Profanações). Em outras palavras, nenhuma individuação é fechada, acabada, impassível de retorno ao pré-individual, assim como somente na continuidade de sua produção, Agamben vai considerar a possibilidade de haver dessubjetivação definitiva e capaz de estancar o retorno da forma de um Eu para a vida - o homo sacer.

Este caráter do Genius de estar sempre presente (mesmo que oculto) de maneira a jamais estar em perfeita harmonia com o Eu, ou seja, na forma de um excedente (e por que não dizer, de um resto) impede que o sujeito possua uma identidade fechada. Ou seja, esse excedente, esse pré-individual sempre presente que é Genius, está para além do sujeito e de sua consciência; para além de seu saber. E é por este motivo que o sujeito proposto por Agamben não pode, como já fora feito outrora, ser pensado como uma substância capaz de ser cognoscível por uma ciência de rigor, ou passível de uma prova ontológica proveniente de um método procedente nos âmbitos da metafísica. Para a possibilidade do conhecimento de Genius sobra somente uma experiência do pré-individual.

Se a presença de Genius é, mesmo que íntima, impessoal e, por isso mesmo, não-cognoscível, então se faz necessário buscar outra maneira de testemunhá-la. Uma vez que Genius é o pólo do sujeito que exige caprichos, ou seja, que cria vontades, então a relação mais fundamental que se pode abrir entre o sujeito e Genius é o desejo de

14 O texto referido foi publicado em 2006, portanto, um ano após a publicação de Profanações. Cf. AGAMBEN, O Que é o Cotemporâneo? e outros ensaios. Chapecó: Argos, 2009. 
fazer-se impessoal; e a única maneira de fazer-se impessoal é entrando em contato com as emoções, entregando-se a elas. Uma vez que, segundo Agamben, é através da emoção (que não tem forma determinada, pode ser segurança ou tremor, angústia ou alegria ${ }^{15}$ ) que o Eu despoja-se de suas propriedades, então, entregando-se ao capricho genioso, o ser pode fazer experiência de Genius.

Todavia, como foi dito, Genius e Eu são incapazes de se emancipar mutuamente. A subjetivação, ou melhor, uma nova subjetivação é sempre inevitável:

Eu sinto que Genius existe em algum lugar, que há em mim uma potencia impessoal que me impele a escrever. [...] Escrevemos para nos tornarmos impessoais, para nos tornarmos geniais, e, contudo, escrevendo, identificamo-nos como autores desta ou daquela obra, distanciamo-nos de Genius, que nunca pode ter a forma de um Eu, e menos ainda de um autor. ${ }^{16}$

Genius não pode ser autor, não pode ser identidade. Todavia, o autor, para se tornar tal, antes deve ser capaz de abandonar-se a Genius. Somente aqueles que "se deixarem abalar e atravessar por ele até que caiam aos pedaços" ${ }^{\prime \prime 17}$ serão capazes de criar, de se fazerem geniais. Somente frente à experiência impessoal de Genius o Eu se desfaz na forma da arte para então, em seu momento posterior, ser restituído como autor. Genius configura-se assim como aquilo frente ao que não se é possível ser sujeito, mas justamente por meio da realização de sua potência, nos tornamos autores, sujeitos, identidade.

Todavia, Agamben avisa que o encontro com Genius é, em suas próprias palavras, terrível. A possibilidade da presença de um elemento pré-individual que nos ultrapasse e nos exceda, não poderia gerar outro sentimento que não o de uma aterradora e inapelável insegurança:

[...] é pânico o sentimento de que Genius venha a exceder-nos e superar-nos sob todos os aspectos, que nos aconteça algo infinitamente maior do que nos parece suportável. Por isso, a maioria dos homens foge aterrorizada frente à parte impessoal própria, ou procura, hipocritamente, reduzi-la à própria estatura minúscula. ${ }^{18}$

A subjetivação que se caracteriza pela tentativa de fugir ou ignorar Genius, Agamben batiza de caráter. Segundo o italiano, caráter é justamente a isenção de Genius revelada na "graça de cada criatura" ${ }^{19}$ Curiosamente, Agamben descreve a manifestação desta graça como a

15 Cf. AGAMBEN, Giorgio. Profanações. São Paulo: Boitempo, 2007, p. 19.
16 Idem, p. 18.
17 Idem, p. 19.
18 Idem, p. 18.
19 Idem, p. 21.


possibilidade de uma afirmação vingativa de Genius que, imprimindo na conduta da vida trejeitos desajeitados e manias várias, retribui o tratamento que recebeu.

Mesmo assim, é justamente esta a maneira pela qual alguém é capaz de não se fixar nem a Genius, nem ao caráter que torna seu ser capaz de amabilidade ${ }^{20}$. Dito de outro modo: o que amamos em alguém é o jeito pelo qual esta pessoa tenta esquivar-se da polarização na forma de uma subjetivação estanque ou de um pré-individual irredutível. O que amamos em outrem é o caminhar frente e verso que a pessoa percorre entre Genius e Eu.

Esta faceta ética de Genius, ou seja, a maneira que ele tem de imprimir sua presença em nossa maneira de aparecer, fazendo de nós amáveis ou não, é um eco da relação que mantemos com o pré-individual. Tal relação é mutável e, mudando, é capaz de mudar nosso caráter. Mais uma vez o Eu aparece entrelaçado com Genius.

Para Agamben, esta relação travada entre o pré-individual e o pessoal sulca a face de Genius bela ou terrivelmente de acordo com nossa conduta; e uma vez que Genius testemunha nossa vida de extremo a extremo, abençoa nosso nascimento e nos deixa na morte, podemos dizer que seu rosto é um outro de nosso rosto. E então, na hora da morte, temos a inevitável revelação genial. Numa espécie de visão eudaimonica, Genius aparece de frente à vida, revelando a esta sua escultura em forma de rosto:

Assim, no momento da morte, a alma vê seu anjo, que lhe vem ao encontro transfigurado, dependendo da conduta da sua vida, ou numa criatura ainda mais bela, ou num demônio horrível, que sussurra: "Eu sou tua Daena, aquela que os teus pensamentos, as tuas palavras e os teus atos formaram". Com uma inversão

Agamben se detém com mais vagar acerca do tema do amor no ensaio La pasión de la facticidad presente em La potencia del pensamiento (Cf.AGAMBEN, Giorgio. La potencia del pensamiento. Barcelona: Editorial Anagrama, 2008) onde aprofunda tal assunto a partir de conceitos da obra de Heidegger. Para Heidegger existe uma co-origenariedade entre o próprio e o impróprio: o ser está sempre numa relação na qual a disposição (propriedade) que o coloca no mundo fica velada ao revelar os entes dados (impropriedade). Para designar tal relação o alemão escolhe o termo facticidade (e que, guardadas as diferenças, objetiva apontar para a mesma relação à qual Agamben faz referência quando fala de um polo entre Genius e Eu). Na facticidade o ser se apresenta sempre como um modo de ser resultante da dialética descrita. Segundo Agamben a escolha heideggeriana do termo 'facticidade' para designar esta relação não é à toa: "Conforme a su etimología, faitis designa aquí todo lo que en un cuerpo humano parece hecho intencionalmente y con arte, y por elle atrae el deseo y el amor. Es como si el ser-tal de un ente, sus "facciones" o sus maneras, se separaran de él en forma de belleza en una en una suerte de paradójica autotrascendencia." Idem, p. 319. Para Agamben, o aparecer da facticidade de outrem no ser que eu mesmo sou só pode se dar como potência passiva, ou seja, como a possibilidade de suportar tal aparecimento. Justamente por isso tratar-se de uma passividade, o amor é uma paixão da facticidade. Ou seja, o que amamos em outrem é aquilo que se esconde ao revelar, o que é exibido ao ser encoberto: "El amor es la pasión de la facticidad, en la que el hombre soporta esta no pertenencia y esta opacidad, y se las apropria custódianas como tales. [...]. En el amor, lo amado viene a la luz, con el amante, en su ser velado, en una facticidad eterna más allá del ser."Idem, p. 331. 
vertiginosa, nossa vida plasma e desenha o arquétipo em cuja imagem fomos criados. ${ }^{21}$

Foi dito acima que o Eu e Genius jamais se identificam, mas também jamais se emancipam. Também foi posto que, da mesma maneira como a realização da potência Genial resulta na subjetivação, fugir da existência do pré-individual termina em consequências que imprimem no hábito da vida marcas bastante nocivas. Nas páginas que se seguirão, este esquema será retomado sob a forma de um novo problema: é possível buscar na leitura da obra de Agamben uma figura da dessubjetivação que nos permita entender de um ponto de vista ético ${ }^{22}$ a figura de Genius? E se o encontro com Genius é terrível, como seria essa imagem? E, não menos importante, qual o estatuto ético que aquele que porta na face as impressões de Genius carrega? É o que tentaremos elucidar a partir de uma análise de O Que Resta de Auschwitz.

\section{Uma experiência de não morte ${ }^{23}$}

\section{O Lager}

Antes de tratarmos do protagonista da dessubjetivação radical, precisamos tecer algumas considerações sobre o lugar onde ele se produziu: o campo de concentração. O paradoxo da soberania que permite a um estado legalmente constituído abrir uma zona territorial onde regra e exceção não são mais distinguíveis, mas imbricadas, e onde o excluído acaba incluso justamente por sua exclusão é o que determina a existência dos Lager. Acerca disso, escreve Duarte:

Para além de sua dimensão propriamente jurídica e carcerária, tais prisões constituem um espaço ambíguo que comporta a inclusão do preso no sistema formal, mas também sua total exclusão, não apenas nas situações em que o detento é sistematicamente torturado, mas também naquelas em que permanece preso após ter cumprido sua pena, e, sobretudo, naqueles momentos de conflito deflagrado: em todas essas ocasiões mostra-se que o detento não é considerado como cidadão portador de direitos temporariamente limitados, mas, sim, como encarnação excessiva - há sempre um excedente de prisioneiros tológico em relação a ética desenvolvido por Heidegger (que é sem dúvida uma das principais influências de Agamben) encontra-se aqui invertido. Em Agamben, como veremos, a questão pela vida é, antes e principalmente uma questão ética.

23 Batizamos a experiência relatada de experiência de não-morte por tratar-se de uma experiência não de morte, mas de sua possibilidade. Como exploraremos melhor a seguir, o homem não pode fazer experiência da morte sem, efetivamente morrer, de tal sorte que relatar a experiência da morte configuraria um absurdo especulativo. 
nessas prisões - da vida que não merece viver e que pode ser descartada e assassinada sem que se cometa delito. ${ }^{24}$

Justamente pelo campo ser, por excelência, o lugar onde se produz a vida que não merece viver é que ali esta pode ser reduzida à sua nudez, dessubjetivada, matável. A vida nua dos campos é a vida que se pode matar sem que, por isso, cometa-se um crime: homo sacer. Figura do direito romano o homo sacer é pensado por Agamben não em sua característica histórica, mas em vistas da urgência de estabelecer um paradigma capaz de iluminar essa vida que encontra-se fora do ordenamento jurídico e inapelavelmente excluída da possibilidade do sacrifício:

Assim como na exceção soberana, a lei se aplica de fato ao caso excepcional desaplicando-se, retirando-se deste, do mesmo modo o homo sacer pertence ao Deus na forma da insacrifibilidade e é incluído na comunidade na forma da matabilidade. A vida insacrificável e, todavia, matável, é a vida sacra. ${ }^{25}$

\section{O muçulmano}

Na obra O Que Resta de Auschwitz, Agamben faz necessário à Shoá ${ }^{26}$ para exibir a figure limítrofe da dessubjetivação. Trata-se daquele que foi objeto de relatos bastante heterogêneos e impactantes por parte dos habitantes do campo de concentração: o muçulmano. ${ }^{27}$ Dentre os diversos relatos de sobreviventes apresentados por Giorgio Agamben acerca do muçulmano, faz-se absolutamente necessário reproduzir, pelo menos em parte, alguns deles. A imagem aterradora (e por muitos evitada) do muçulmano e sua difícil apreensão motivou o autor a reafirmar as palavras de Primo Levi, segundo as quais toda a ética deve ser repensada, pois nunca considerou esta parte, por mais nefasta que possa ser, do humano: o seu não-humano constituinte. Seguem abaixo trechos de relatos: Janeiro : Forense Universitária, 2010, p. 284.

AGAMBEN, Giorgio. Homo Sacer: o poder soberano e a vida nua I. Belo Horizonte: Editora UFMG, 2010, p. 84. Itálicos do autor.

Agamben rejeita o uso do termo holocausto. Segundo ele, a origem deste apresenta uma semântica religiosa acerca daquilo que é sacrificado em oferta a deus além de, no seu desenrolar histórico, ganhar um caráter anti-semita: "[...] no caso do termo "holocausto", estabelecer uma vinculação, mesmo distante, entre Auschwitz e o olah bíblico (sacrifício), e entre a morte nas câmaras de gás e a "entrega total a causas sagradas e superiores" não pode deixar de soar como uma zombaria. O termo não só supõe uma inaceitável equiparação entre fornos crematórios e altares, mas acolhe uma herança semântica que desde o início traz uma conotação antijudaica. Por isso, nunca faremos uso desse termo." AGAMBEN. Giorgio. O Que Resta de Auschwitz: o arquivo e a testemunha (Homo Sacer III). São Paulo : Boitempo, 2008, p. 26

27 Apelidados de muçulmanos, aqueles que experienciaram a dessubjetivação radical nos campos não eram fiéis do Islã, mas judeus. Segundo Jeanne Marie Gagnebin: "A etimologia dessa expressão "muçulmano" é obscura; de minha parte não consigo não ouvir, em todas laboriosas explicações, como que uma certa desforra de caráter racista na boca das vítimas do anti-semitismo." GAGNEBIN, Jeanne Marie. Apresentação. In: AGAMBEN, Op. Cit., p. 13. 
Esse ser imbecilizado e sem vontade, arrastando seus tamancos de madeira pelo chão, acabou caindo precisamente nos braços daquele das SS, que the deu um grito e the desferiu uma bordoada na cabeça. [...]. Lançou-se sobre ele desferindo-lhe pontapés no abdômen e, depois que o infeliz já estava caído sobre seus próprios excrementos, continuou a batê-lo na cabeça e no tórax. O muçulmano não se defendia. Ao primeiro golpe se dobrou ao meio, e depois de mais alguns golpes já estava morto. ${ }^{28}$ Quando continuava a emagrecer a expressão do rosto também mudava. O olhar tornava-se opaco e o rosto assumia uma expressão de indiferença, mecânica e triste. Os olhos ficavam cobertos por um véu, as órbitas, profundamente cavadas. A pele tomava um colorido cinza-pálido, tornava-se sutil, dura, parecida com papel e começava a descamar-se. Era muito sensível a qualquer tipo de infecção e contágio, especialmente à sarna. Os cabelos eriçavam-se, tornavam-se opacos e se rompiam facilmente. A cabeça se encompridava, as maçãs do rosto e as órbitas ficavam bem evidenciadas. [...] À medida que o estado de desnutrição aumentava, os edemas se difundiam [...] inicialmente na parte inferior das pernas, depois nas coxas, nas nádegas, nos testículos e até mesmo no abdômen. ${ }^{29}$

Mas, para além de toda a incrível deterioração corporal e incapacidade de cuidado apresentado pelo muçulmano, Agamben vai se ocupar em seu estudo de suas características singulares quanto à ausência de vida de relação (bios) e redução da vida à vida nua (zoé):

[...] os doentes tornavam-se indiferentes a tudo o que acontecia ao seu redor. Eles se auto-excluíam de qualquer relação com o seu ambiente. Quando ainda eram capazes de se mover, isso se dava em câmara lenta, sem que dobrassem os joelhos. ${ }^{30}$

A história - ou melhor, a não-história - de todos os "muçulmanos" que vão para o gás é sempre a mesma: simplesmente, acompanharam a descida até o fim, como os arroios que vão até o mar. [...]. A sua vida é curta, mas seu número é imenso; são eles, os "muçulmanos", os submersos, são eles a força do campo: a multidão anônima, continuamente renovada e sempre igual dos não-homens que marcham e se esforçam em silêncio; já se apagou neles a centelha divina, já estão tão vazios que nem podem sofrer. Hesita-se chama-los vivos; hesita-se chamar "morte" à sua morte, que eles já nem temem, porque estão esgotados demais para poder compreendê-la. ${ }^{31}$

A absoluta passividade do muçulmano e a aniquilação total de sua vontade é o resultado do cruzamento entre a deterioração absoluta

\footnotetext{
Ryn, Z. e Klodzinski, S."An der zwischen Leben und Tod:Eine Studie über die Erscheinung des 'Muselmanns' im Konzentrationslager" In: Auschwitz-Hefte: Weinheim/Basel, 1987. Apud. AGAMBEN, Op. Cit., pp. 49, 50.

Idem, pp. 50, 51.

Idem, p. 51.

LEVI P.: É Isto um Homem?. Rio de Janeiro: Rocco, 1998. Apud. AGAMBEN, Op. Cit., p. 51, 52.
} 
do organismo biológico e a submersão desenfreada do sujeito frente à extremidade de sua situação-limite: a dessubjetivação radical, a situação onde o humano dá lugar ao não-humano, onde,por detrás da face estóica do Eu aparece o rosto de Genius, em feições terríveis. Os sulcos que Genius imprime no rosto do muçulmano levaram àqueles que se detiveram no tema (sobreviventes ou não) a pensar a medida de humanidade que resiste em uma pessoa que ficou, aparentemente, reduzido à vida biológica.

Para podermos inquirir o fundamento da vida revelado pelo dessubjetivado, devemos seguir esta trilha retomando a análise de Genius. Como dito, o sentimento que acompanha a maioria dos homens ante o encontro com o anjo genial é de pânico, uma vez que o encontro é terrível. Justamente por este motivo, os homens que estão em vias de habitar a zona onde o homem exibe o seu não-homem ${ }^{32}$ agarram-se a qualquer coisa para evitar sua dessubjetivação. Dessubjetivar-se é aqui não mais lutar contra Genius, mas aceitar sua visita, mesmo que terrível e, talvez, sem volta:

O muçulmano é, portanto, [...], alguém que abriu mão da margem irrenunciável de liberdade e que, consequentemente, extraviou qualquer traço de vida afetiva e de humanidade. Essa passagem para além do "ponto sem retorno" é uma experiência tão desconcertante , tornando-se nesta altura, [...] uma separação entre humano, a ponto de eliminar da testemunha não apenas todo sentido de piedade, mas também de lucidez, induzindo-o a confundir o que, de modo algum, deveria ser confundido. ${ }^{33}$

O inquérito que estamos instalando ainda deverá contar com mais uma dificuldade. Como bem relembra Primo Levi ${ }^{34}$, o testemunho daquele que submergiu, a "testemunha integral", não era capaz de oferecer palavra. A possibilidade de relatar a experiência vivida pelo muçulmano é, como explica Castro: “[...] o encontro entre duas impossibilidades: a do próprio testemunho e a de sua linguagem. [...] A língua do testemunho é uma língua cujo significado funde-se no não significado. Auschwitz é, nesse sentido, o intestemunhável. ${ }^{35}$

O muçulmano permanece em silêncio a contemplar a mais terrível faceta de Genius, a única que lhe poderia ter sido ofertada: a Górgona.

\section{A Górgona}

O muçulmano penetrou em uma região do humano - pois, negar-lhe simplesmente a humanidade significaria aceitar o veredicto das SS, repetindo seu gesto - onde, dignidade e respeito de si 
não são de nenhuma utilidade, como também não são uma ajuda exterior. Se existe porém, uma região do humano em que tais conceitos não têm sentido, não se trata de conceitos éticos genuinos, porque nenhuma ética pode ter a pretensão de excluir do seu âmbito uma parte do humano, por mais desagradável que seja de ser contemplada. ${ }^{36}$

É justamente por perceber a gravidade ética da questão pelo muçulmano ("porcos, não homens" - sentenciam os oficiais de Auschwitz), na qual a natureza do homem se põe em cheque, permitindo que se pense na transformação do homem em inumano, que Giorgio Agamben vê como absolutamente necessário uma investigação que evidencie o contrário. É importante ressaltar que Agamben recorre ao uso do termo "não-humano", como aquilo que funda o homem mas sobre o qual ele não tem domínio (Genius), e não o termo "inumano", que terminaria por excluir o humano. Em outras palavras, o não-homem é a figura do que excede, do que sobra; é neste horizonte que se deve pensar o título da obra O Que Resta de Auschwitz.

Para entendermos sob a luz de Genius o tema dessa morte não morrida e o movimento interno da vida no desenrolar da dessubjetivação - que levará Agamben a forçar as categorias heideggerianas para concluir que nos campos a impropriedade toma a forma da propriedade -, precisamos verificar a alegoria, mais uma vez proposta por Primo Levi, através da qual se afirma que o muçulmano é "quem viu a Górgona". A transformação de Genius em sua mais terrível face termina por revelar ao muçulmano uma antecipada eudaimonia revelando, fora de hora, o fundamento humano. Genius transfigurado em Górgona é senão: "O rosto proibido, impossível de olhar porque produz a morte, é, para os gregos, um não-rosto e, como tal, nunca é designado com o termo prósopon. Contudo, tal visão impossível é, para eles, ao mesmo tempo, absolutamente inevitável" ${ }^{37}$

O que é revelado ao muçulmano em sua visão genial é somente a aterradora face do que estaria vedado ao homem. ${ }^{38} \mathrm{~A}$ influência que o pensamento de Heidegger exerce sobre Agamben é aqui bastante evidente. Mas não é sem alguma discordância. Em Ser e Tempo ${ }^{39} \mathrm{o}$ alemão distinguia entre uma relação imprópria do ser-aí para com a morte, e uma apropriação que desta derivaria, resultando numa experiência autêntica da própria existência (na qual a morte pode ser entendida como possibilidade da minha morte, e não mais a morte

AGAMBEN, Op. Cit., pp.70, 71.

AGAMBEN, O Que Resta de Auschwitz, p. 60.

38 Giorgio Agamben cita a conferência $O$ Perigo de Heidegger, segundo o qual "[...] a essência da morte está vedada ao homem." HEIDEGGER, M. O Perigo. In: AGAMBEN, O Que Resta de Auschwitz, p. 80.

39 HEIDEGGER, Martin. Ser e Tempo. Campinas: Editora da Unicamp; Petrópolis: Editora Vozes. 2012. 
de outrem $\left.{ }^{40}\right)$. Heidegger, após separar com um anátema o modo próprio e o impróprio do ser-aí se relacionar para com a morte, instituiu, a partir de analítica existencial, uma hierarquia radical que coloca a propriedade como única possibilidade de apropriação ontológica da "possibilidade insuperável":41

[...] ficou caracterizado o ser-para-a-morte impróprio, esboçando-se assim, enquanto proibição, o modo como o ser-para-a-morte próprio não pode ser. ${ }^{42}$

[...]. O ter-por-verdadeiro da morte - morte que é somente cada vez a própria - mostra uma certeza de outro tipo e mais originária do que a relativa a um ente que vem-de-encontro no interior-do-mundo ou a relativa a objectos formais; pois ele está certo do ser-no-mundo. Como tal, não exige somente um determinado comportamento do Dasein, mas o Dasein na plena propriedade de sua existência. Somente no adiantar-se, o Dasein pode se assegurar de seu ser mais-próprio em sua totalidade insuperável. De onde decorre que a evidência de uma imediata datidade das vivências do eu e da consciência deva ser necessariamente preterida em favor da certeza contida no adiantar-se. ${ }^{43}$

Já em O Que Resta de Auschwitz, Agamben mostra que no Lager a impropriedade (que caracteriza-se pela banalidade cotidiana, diversão, etc, e, no caso da morte, pelo medo, desepero e outros.) não é mais distinguível da propriedade. Nos campos, a impropriedade assume a forma da propriedade e a fuga do encontro com seu Genius-Górgona, não é mais uma escolha. ${ }^{44}$ Mesmo assim, não podemos dizer que o muçulmano conhece sua até então vedada essência de morte. Não se pode afirmar que sua visão é uma experiência de antecipação da morte, ou

"Quanto mais adequada seja a apreensão fenomênica do já-não-ser-"aí" do finado, tanto mais claramente se mostra que esse ser-com o morto não experimenta precisamente o ser-chegado-ao-final próprio do finado. A morte se desvenda sem dúvida como perda, porém mais como uma perda que os sobreviventes experimentam, e no padecer pela perda, não se tem acesso, porém, à perda-do-ser que como tal o que morre "padece". Não experimentamos em sentido genuíno o morrer dos outros, mas no máximo só estamos sempre presentes a ele. [...]. O propósito de fazer da morte experimentada em outros o tema da análise do final e da totalidade do Dasein não consegue dar nem ôntica, nem ontologicamente o que se presume possa dar." Idem, p. 661.

41 Idem, p. 725.

42 Idem, p. 717.

43 Idem, pp. 727, 729.

44 Mesmo sendo irrelevante para o inquérito acerca de Auschwitz, é importante relembrar que, como dito no ensaio Genius, a dessubjetivação não se dá, necessariamente, com a destruição da vontade (este modo está ligado intrinsecamente com Auschwitz), mas pode justamente permitir uma decisão radical, ou seja, a vontade de não. Contrapõe-se ao muçulmano a figura de Bartleby, o escrivão fictício de Melville que se recusa a passar do impessoal (Genius) para o pessoal (Eu). Ao muçulmano não foi destinada a decisão de encontrar Genius. Diferente é o caso do personagem tratado por Agamben em A Comunidade Que Vem. Segundo o autor, Bartleby, "um escrivão que não deixa simplesmente de escrever, mas 'prefere não', é a figura extrema deste anjo, que não escreve outra coisa do que a sua potência de não escrever." AGAMBEN, Giorgio. A Comunidade Que Vem. Lisboa : Editorial Presença, 1993, p. 35 
mesmo de morte em sentido próprio; o muçulmano é aquele cuja experiência o faz habitar o limite, onde a mortalidade própria e imprópria não são mais discerníveis, mas amalgamadas. Por isso mesmo trata-se de uma não-morte, ou, se preferir: o muçulmano faz experiência de sua não-mortalidade, não por ser o avesso da mortalidade, mas pela impossibilidade de dizê-lo, de distingui-lo. A marca que a Górgona imprime no rosto do muçulmano é a marca da ambiguidade:

[...] em um caso, ele se apresenta como o não-vivo, como o ser cuja vida não é realmente vida; no outro, como aquele cuja morte não pode ser chamada de morte, mas apenas fabricação de cadáveres. Por outras palavras, como a inscrição na vida de uma zona morta e, na morte, de uma zona viva. [...]. O muçulmano é o não-homem que se apresenta obstinadamente como homem, e o humano que é impossível dissociar do inumano. ${ }^{45}$

A condição na qual se encontra o muçulmano é, ao mesmo tempo, uma condição de degradação humana que jamais deve ser estetizada, e uma condição na qual se exibe o fundamento negativo do sujeito, a partir do qual o projeto de estabelecer um novo discurso acerca da ética aqui inquirido deve se guiar. Genius franzido à Górgona se apresenta como a experiência máxima daquilo que não é:

A grandeza - mas também a miséria - da potência humana está no fato de ela ser, também e sobretudo, potência de não passar ao ato, potência para as trevas. Se se considera que skotos (escuro), no grego homérico, é antes de tudo as trevas que invadem o homem no momento da morte, é possível medir todas as consequências dessa vocação anfíbia da potência. A dimensão que ela destina ao homem é o conhecimento da privação, ou seja, nada menos que a mística como fundamento secreto de todo o seu saber e de todo o seu agir. ${ }^{46}$

\section{A Vergonha}

\section{Superstes}

Giorgio Agamben identifica etimologicamente dois termos em latim que designam testemunha: um deles é testis, aquele que se coloca no lugar de quem observou a origem de uma contenda e desta pode falar; literalmente "terceiro". A testemunha de Auschwitz tem pouco a ver com este caso. Antes, o muçulmano é aquele que se tornou superstes, ou seja: 
[...] aquele que viveu algo, atravessou até o final um evento e pode, portanto, dar testemunho disso. [...] Mas isso também significa que o seu testemunho não tem a ver com o estabelecimento dos fatos tendo em vista um processo (ele não é suficientemente neutro para tal, não é um testis). Em última análise, não é o julgamento que lhe importa - menos ainda o perdão. [...] Aliás, parece que lhe interessa apenas o que torna impossível o julgamento, a zona cinzenta em que as vítimas se tornam carrascos, e os carrascos, vítimas. ${ }^{47}$

Mas o que testemunhou o supérstite do Lager? O que o rosto terrível do Genius-Górgona revelou ao muçulmano? Certamente não foi, nem poderia ter sido, nenhum conteúdo específico (se na experiência da dessubjetivação, o sujeito desaparece, logo também desaparecem possíveis objetos de experiência. De tal forma que podemos afirmar: dessubjetivar-se, encontrar-se com Genius, é fazer experiência da negatividade). Se "emocionar-se significa sentir o impessoal que está em nós, fazer experiência de Genius como angústia ou alegria, segurança ou tremor", ${ }^{48}$ qual seria então o afeto que se revela no rosto daquele que submergiu à Górgona?

\section{Vergonha sem culpa: um eterno retorno}

As feições impressas por Genius no rosto do muçulmano são as marcas da vergonha. Quando do primeiro encontro dos internos de Auschwitz com soldados que não vinham mais sob a incumbência de mantê-los como homo sacer, o que estes últimos encontraram foi, em meio aos amontoados de corpos, um punhado de sobreviventes não-humanos. Incapazes de demonstrar alegria ou alívio, os muçulmanos mantinham-se envergonhados:

Não acenavam, não sorriam; pareciam sufocados, não somente por piedade, mas por uma confusa reserva, que selava as sua bocas e subjugava os seu olhos ante o cenário funesto. Era a mesma vergonha conhecida por nós, a que nos esmagava após as seleções, e todas as vezes que devíamos assistir a um ultraje ou suportá-la: a vergonha que os alemães não conheceram, aquela que o justo experimenta ante a culpa cometida por outrem. ${ }^{49}$

É praticamente unânime entre os sobreviventes a relação entre a vergonha da dessubjetivação radical e a culpa por ter sobrevivido. Mas que tipo de culpa poderia ter alguém que não foi desleal, não roubou 
comida ou ajudou a matar seus companheiros de Lager ${ }^{50}$ Como é possível haver uma simples aceitação dessa culpa que não lhe é legítima? De fato, se a culpa é praticamente unânime, sua simples aceitação não o é. Antes ela pode ser bastante litigiosa e se impor não por um senso de justiça ou moral (Eu), mas como uma emoção (emoção do Genius-Górgona, a vergonha). Ou, ainda, rechaçada, como faz Levi:

\author{
Desde então, em hora incerta, \\ essa pena retorna, \\ e se não encontra quem a escute \\ lhe arde no peito o coração. \\ Revê os rostos dos seus companheiros \\ lívidos à primeira luz, \\ cinzentos de pó de cimento, \\ indistintos devido à névoa, \\ tingidos de morte nos sonos inquietos: \\ de noite batem os queixos \\ sob a grave demora dos sonhos, \\ mastigando um nabo que não há. \\ "Para trás, fora daqui, gente submersa! \\ Vão embora! Não suplantei a ninguém, \\ não tirei o pão de ninguém, \\ ninguém morreu no meu lugar. Ninguém. \\ Voltem à nevoa de vocês. \\ Não é minha culpa se eu vivo e respiro, \\ e como e bebo e durmo e tenho vestidos."
}

Entender a natureza do conflito entre inocência e culpa que se impõem ao muçulmano não é tarefa fácil. Levi não aceita a culpa que lhe é trazida pelos seus fantasmas. Mas, com relação aos outros habitantes do Lager que, aceitando o fardo sabem-se inocentes, mas sentem-se ao mesmo tempo culpados, tal estado de coisas revelaria que, ou existe uma cisão entre o Eu (inocência) e Genius (culpa), ou então inocência e culpa não configurariam antônimos. De certa feita, Agambem escreveu, em uma reflexão sobrede Kafka, algumas considerações que nos fazem acreditar que o filósofo estaria propenso a aceitar a segunda hipótese:

Cada homem intenta um processo calunioso contra si próprio. [...] a culpa não existe - ou, antes, a única culpa é a autocalúnia, que consiste no acusar-se de uma culpa inexistente (isto é, da sua própria inocência [...]). $\mathrm{O}$ acusado, na medida em que se autocalunia, sabe perfeitamente estar inocente, mas, na medida em que acusa, sabe igualmente ser culpado de calúnia, merecer

50 Há de se lembrar que, em Auschwitz, bem como em outros campos, formou-se o Sonderkommando - pequenos "batalhões" de judeus que ajudavam no funcionamento das câmaras de extermínio em massa. Portanto, a não ajuda no processo de extermínio se estende à maioria dos sobreviventes, não a todos.

51 LEVI, P. Ad Ora Incerta In: Opere. Torino: Einaudi, 1988. Apud. AGAMBEN, Op. Cit., p. 95, 96. O último verso é citação literal que Levi faz de "A Divina Comédia". 
seu labéu. [...] Porque se a acusação é falsa e se, por outro lado, acusador e acusado coincidem, então é a própria implicação fundamental do homem no direito que é posta em questão. O único modo de alguém afirmar sua inocência frente à lei [...] é, neste sentido, acusar-se falsamente. ${ }^{52}$

Somente mediante acusação um processo se inicia. Quando calunia a si mesmo, o caluniador se deixa, inevitavelmente, capturar pelo processo numa singular identificação entre acusador e acusado, inocente e culpado. A autocalúnia do sobrevivente não é mais do que a ficha de inscrição através da qual a testemunha experimenta o falso sentimento de "alguém morreu no meu lugar" 53 . Se inocência e culpa não são, como costuma-se pensar, antônimos, mas elementos reciprocamente fundantes (de maneira que um sequer exista sem o outro), declarar-se inocente tem na culpa sua decorrência necessária. A relutância de Primo Levi - um dos poucos muçulmanos que sobreviveram e voltaram a subjetivar - em aceitar a culpa que os fantasmas do Lager tentam lhe impor em hora incerta, é a luta para fugir da inevitável identificação entre culpa e inocência: é a luta para aceitar Auschwitz sem ressentimento.

Aceitar a vergonha do Lager sem a culpa que os fantasmas dos submersos trazem parece ser a tarefa mais difícil para o sobrevivente. Lembremos-nos da ruptura (inaugural de um novo e predominante discurso no século XX) acerca da ética promovida pelo argumento nietzscheniano do eterno retorno: ${ }^{54}$ tal consiste em liberar o remorso por meio de uma aceitação positiva, uma querência integral do passado, com todas as alegrias e dores, sabores e dissabores. Após os campos, alguns sobreviventes, ao encarar o pensamento de Nietzsche chegaram, inclusive, a propor um retroceder da ética e um reatrelamento desta com o ressentimento. ${ }^{55}$ Diferente pode ser o caso de Primo Levi. Capaz de testemunhar a volta de Auschwitz sem o ressentimento, ele é revisitado pela Górgona. Justamente por se deixar atravessar por ela é que Levi pode afirmar que "não se pode querer que Auschwitz retorne

53 Assumir que a morte de outrem substituí a morte própria é uma maneira do sujeito ser reconduzido ao Eu, ou seja, subjetivar-se. Assim sendo, a enunciação "alguém morreu no meu lugar" não pode corresponder a um testemunho do Genius-Górgona; não nos fornece elemento para pensar a dessubjetivação radical de Auschwitz.

54 "E se um dia, ou uma noite, um demônio lhe aparecesse furtivamente em sua mais desolada solidão e dissesse: 'Esta vida, como você a está vivendo e já viveu, você terá de viver mais uma vez e por incontáveis vezes; e nada haverá de novo nela, mas cada dor e cada prazer e cada suspiro e pensamento, e tudo o que é inefavelmente grande e pequeno em sua vida, terão de lhe suceder novamente, tudo na mesma sequência e ordem [...]. A perene ampulheta do existir será sempre virada novamente - e você com ela, partícula de poeira!'. - Você não se prostaria e rangeria os dentes e amaldiçoaria o demônio que assim falou? [...] a questão em tudo e em cada coisa, "Você quer isso mais uma vez e por incontáveis vezes?", pesaria sobre os seus atos como o maior dos pesos! Ou o quanto você teria de estar bem consigo mesmo e com a vida, para não desejar nada além dessa última, eterna confirmação e chancela?" NIETZSCHE, Friedrich W. A Gaia Ciência. São Paulo : Companhia das Letras, 2001, p. 230. 
eternamente, porque, na verdade, nunca deixou de acontecer, já se está repetindo sempre." ${ }^{56}$ Segundo Agamben:

O problema ético mudou radicalmente de forma nesse caso: já não se trata de derrotar o espírito de vingança para assumir o passado, para querer que ele volte eternamente. Nem se trata de manter com firmeza o inaceitável por meio do ressentimento. O que temos agora pela frente é um ser para além da aceitação e da rejeição, do eterno passado e do eterno presente - um acontecimento que eternamente volta, mas que, precisamente por isso, é absoluta e eternamente não-assumível. Para além do bem e do mal não está a inocência do devir, porém uma vergonha não só sem culpa, mas, por assim dizer, já sem tempo. ${ }^{57}$

\section{Vergonha: dessubjetivação e subjetivação}

Segundo Giorgio Agamben, a vergonha é a emoção que se produz na vida entregue a algo que não pode ser assumido, mas do qual também não se pode ser separado. O que se experiencia na vergonha não é nada senão a impossibilidade irrefutável de não podermos nos separar daquilo que não queremos assumir. Provindo de nossa mais íntima condição, envergonhar-se é, aqui, fazer experiência do grau mais radical de dessubjetivação:

Envergonhar-se significa: ser entregue a um inassumivel [inassumibile]. No entanto, este inassumível não é algo exterior, mas provém da nossa própria intimidade; é aquilo que em nós existe de mais íntimo [...]. O eu é, nesse caso, ultrapassado e superado pela sua própria passividade, pela sua sensibilidade mais própria; contudo, esse ser expropriado e dessubjetivado é também uma extrema e irredutível presença do eu a si mesmo. [...] $\mathrm{Na}$ vergonha, o sujeito não tem outro conteúdo senão a própria dessubjetivação, convertendo-se em testemunha do próprio desconcerto, da própria perda de si como sujeito. Esse duplo movimento, de subjetivação e de dessubjetivação, é a vergonha..$^{58}$

Exemplos de vergonha que seguem o raciocínio descrito são fáceis de listar: a nudez própria, as necessidades do corpo e as doenças estariam à mão para dissertarmos a respeito. Mas nenhum destes exemplos combinaria com a condição do dessubjetivado do Lager. Então, o que de inassumível testemunha o muçulmano? O que o não-homem do campo vê que lhe enrubesce as têmporas? Vejamos o testemunho de Antelme: 
A SS continua chamando: Du Komme hier (Tu, vem cá). É outro italiano que sai. Um estudante de Bolonha. Conheço-o, olho para ele e vejo que seu rosto ficou vermelho. Olhei-o atentamente, aquele surpreendente rubor o terei sempre nos olhos. Tem o ar confuso, e não sabe o que fazer com suas mãos... Ficou vermelho logo depois que a SS lhe disse: $\mathrm{Du}$ - Komme hier! Olhou em volta de si antes de se avermelhar, mas era precisamente ele que queriam e então ficou vermelho quando não teve mais dúvidas. A SS procurava um homem, um qualquer, para matar, havia "escolhido" a ele. ${ }^{59}$

O rubor que cobre as bochechas do jovem que se percebe escolhido a esmo para ser morto pode, finalmente, nos dar uma pista para respondermos às perguntas acima. Frente a frente com seu algoz, o rapaz que está prestes a ser fuzilado tem a revelação de Genius, o anjo "que os teus pensamentos, as tuas palavras e os teus atos formaram" 60 - uma experiência de não-morte. O jovem muçulmano não se envergonha da atrocidade da guerra, ou mesmo por "morrer no lugar de um outro". O muçulmano envergonha-se de ter sua máxima intimidade exposta fora de hora. Sua vergonha é a vergonha de quem tem na morte seu inassumível. A experiência de não-morte é a experiência que enrubesce seus traços. A imagem que a Górgona imprime no rosto de seu supérstite é a vermelhidão de quem não pode se separar da mortalidade.

Se aquele que experimenta sua não-morte testemunha nada além de si-mesmo, se aquele que observa o Genius-Górgona faz de si mesmo sujeitado, se na dessubjetivação do muçulmano o sujeito assiste seu próprio desmantelamento, então podemos dizer: quando subjetivação e dessubjetivação coincidem aparece o sentimento que funda o sujeito. Trata-se da vergonha.

Fazer de si mesmo sujeito da própria passividade é, como diz Agamben, ter como atividade de si, para com si a receptividade. $\mathrm{Na}$ vergonha, a passividade constituinte do duplo movimento de subjetivação e dessubjetivação devem acompanha-los:

Assim, como forma da subjetividade, a passividade está, constitutivamente cindida em um pólo puramente receptivo (o muçulmano) e um pólo ativamente passivo (a testemunha), de maneira tal, porém, que esta cisão nunca saia de si mesma, que nunca separe totalmente os dois polos, tendo sempre, pelo contrário, a forma de uma intimidade, da entrega de si a uma passividade, de um fazer-se passivo, em que os dois termos ao mesmo tempo se distinguem e se confundem. ${ }^{61}$ 
Ser sujeito da própria dessubjetivação é a única maneira de testemunhar o desmantelamento do Eu frente à Genius. Logo, a vergonha é o mais fundamental dos sentimentos perpetrados pelo anjo genial.

\section{O testemunho}

A não sincronia entre sujeito e dessubjetivação que caracterizam a vergonha é, curiosamente, a mesma impossibilidade da identificação entre arte (Genius) e autor (Eu). O poeta dessubjetiva-se na realização da obra de arte e volta a subjetivar na sua assinatura. Os poetas Pessoa, Keats, Rimbaud, entre muitos outros, sabem disso muito bem, sabem que o conteúdo da poesia dista de si, dista do autor. Ora, se o conteúdo da poesia não é nenhum conteúdo específico (experimentar Genius é fazer experiência da negatividade), então, para que o discurso poético ganhe a sua instância de fala ou, como dizem os linguistas, o seu shifter (eu, tu, eles, etc.) uma dessubjetivação é absolutamente inevitável, já que o que não tem conteúdo nem objeto, não pode ter sujeito.

A propósito de uma reflexão sobre os shifters e a dessubjetivação, um trecho de Fausto acerca de uma carta de Rimbaud pode ser ilustrativo:

Poder-se-ia dizer: perder-se, não estar mais em si, deixar-se atravessar como meio para chegar ao desconhecido. Um pouco adiante, esse pensamento toma sua forma mais radical, numa espécie de reversão do cartesianismo: "Está errado dizer: Eu penso. Deveríamos dizer: Pensam-me." On me pense, construção em que "eu" torna-se objeto de on, pronome pessoal impessoal, em quem me é arrebatado por uma força exterior e sem rosto. ${ }^{62}$

Se, para que a apropriação da instância do discurso aconteça, é necessário que o Eu seja pensado, e não mais pensante, então o Eu é sujeito de Genius; por ele produzido novamente a cada enunciação.

O paradoxo aqui aberto que se interpõe entre experiência e fala, revelando uma ausência do falante, leva Agamben a fazer do sujeito uma figura do mutismo, cuja voz resigna-se a uma glossolalia que se empresta a Genius: um conjunto de fonemas que não se articulam pelo $\mathrm{Eu}$, mas antes, pela língua:

No presente absoluto da instância do discurso, subjetivação e dessubjetivação coincidem em todos os pontos, e tanto o individuo em carne e osso quanto o sujeito da enunciação calam totalmente. Isso também pode ser expresso dizendo que quem fala não é o individuo, mas a língua; isso, porém, nada mais significa senão que - não se sabe como - a palavra atingiu uma impossibilidade de falar. ${ }^{63}$ 
A cada nova apropriação do discurso, Genius produz um novo sujeito. A citação que Agamben faz de uma carta de Fernando Pessoa ${ }^{64}$ na qual este comenta a aparição de seu heterônimo Alberto Caeiro e o posterior retorno do primeiro - a resposta de Pessoa a Caeiro. Para Agamben, três sujeitos distintos se revelam neste processo:

Há, antes de tudo, o individuo psicossomático Fernando Pessoa, [...]. Com relação a esse sujeito o ato poético não pode deixar de implicar uma dessubjetivação radical, que coincide com a subjetivação de Alberto Caeiro. No entanto, uma nova consciência poética, algo similar a um autêntico ethos da poesia, só aparece quando Fernando Pessoa - que sobreviveu à sua despersonalização e volta a um si mesmo, que é e, ao mesmo tempo, não é mais, o primeiro sujeito - compreende que deve reagir frente à sua inexistência como Alberto Caeiro, que deve responder por sua dessubjetivação. ${ }^{65}$

Mas, se a testemunha do Lager está radicalmente dessubjetivada (e, portanto, é sujeito unicamente de sua dessubjetivação), como é possível tal coisa como o testemunho? De que pode falar aquele que teve as têmporas enrubescidas pela experiência de não-morte? Agamben estaria afirmando que não existe sujeito no testemunho?

A propósito de uma solução, ajuizada por Agamben, para a querela acerca da originariedade do discurso, entre Heidegger e Rilke, escreve Valentim:

Diferentemente, o viver, [...] implica ser em vista de outro ou, como formula Agamben, uma "dessubjetivação" fundamental e constitutiva: a impossibilidade radical, para o vivente humano, de ser-aí enquanto referência para todo e qualquer ente, sobretudo para si mesmo. ${ }^{66}$

[...] a poesia deve representar um verdadeiro impossível ontológico: a impropriedade como potência originária da palavra. Pois a "possibilidade", ontologicamente inapropriável, da poesia repousaria sobre nada menos que a suspensão daquilo mesmo que pelo que se orienta fundamentalmente a perspectiva ontológica, a saber, a constituição de um discurso propriamente humano. ${ }^{67}$

O sujeito do testemunho seria a impessoalidade genial e, portanto, o não-humano? Quem é que reporduz o testemnunho no momento em que o sujeito auto-referente não pode mais? Nas palavras de Agamben:

64 Cf. Idem, pp. 122 e 123.

$65 \quad 62 / d e m$, p. 123.

66 VALENTIM, M. A. "A outra interpretação": sobre os limites de um conceito filosófico de poesia. In: FÉLIX W.; OLIVEIRA, R.; PERIUS, C. (orgs.) VI Simpósio de Filosofia da UEM - Estética: Ontem e Hoje, 2012, Maringá. Estética: Ontem e Hoje - Anais do VI Simpósio de Filosofia da UEM. Maringá: Departamento de Filosofia da Universidade Estadual de Maringá, 2012, p. 21. 
[...] isso significa que quem de fato dá testemunho no homem é o não-homem, ou seja, que o homem não é senão o mandatário do não-homem, aquele que lhe empresta a voz. Ou então, que não existe um titular no testemunho; que falar, dar testemunho significa entrar em um movimento vertiginoso, em que algo vai a pique, se dessubjetiva integralmente e emudece, e algo se subjetiva e fala, sem ter - propriamente - nada a dizer [...]. ${ }^{68}$

Mas o que pode ser posto no lugar do sujeito moderno que confiava à moral e ao ressentimento sua ética? O testemunho; ou seja, aquilo que sobra de toda tentativa de aniquilar subjetivamente a humanidade - o não-humano. Da terrível experiência de Auschwitz sobra a vergonha do dessubjetivado. Aquilo que sobrevive ao humano é justamente seu fundamento e, ao mesmo tempo, aquilo que lhe excede. É por isso que Agamben intitula seu livro não com uma pergunta, mas com uma afirmação. Resta de Auschwitz o que as câmaras e os fornos crematórios não conseguiram destruir: a certeza de que o sujeito emerge do olhar enrijecedor da Górgona.

Para além do Eterno Retorno de Auschwitz, resta a relação que o homem pode ter com seu não-humano constitutivo. Resta o saber de que existe algo que rege nossa existência, mas que sempre nos escapa: "Genius é a nossa vida, enquanto não nos pertence." ${ }^{69}$

\section{Referências}

AGAMBEN, Giorgio. A Comunidade Que Vem. Lisboa : Editorial Presença, 1993.

. A Imanência Absoluta. In: ALLIEZ, E. Gilles Deleuze: uma vida filosófica. Rio de Janeiro : Editora 34, 2000.

A Linguagem e a Morte. Belo Horizonte : Editora

UFMG, 2006.

A Potência do Pensamento. In: Revista do Departamento de Psicologia. UFF, 2006. Disponível em: http:/ / www.scielo.br/scielo. php? script=sci_arttext\&pid=S0104-80232006000100002.

Estâncias - a palavra e o fantasma na cultura ocidental. Belo Horizonte: Editora UFMG, 2007.

Homo Sacer: o poder soberano e a vida nua I. Belo Horizonte: Editora UFMG, 2010. 
. Infância e História: destruição da experiência e origem da história. Belo Horizonte : Editora UFMG, 2005.

. La potencia del pensamiento. Barcelona: Editorial Anagrama, 2008

. Nudez. Lisboa : Relógio D'água, 2009.

. O Que Resta de Auschwitz: o arquivo e a testemunha (Homo Sacer III). São Paulo : Boitempo, 2008.

. Profanações. São Paulo : Boitempo, 2007.

. What is a Paradigm?. Disponível em: http:/ / www.egs.edu/ faculty/giorgio-agamben/articles/what-is-a-paradigm/

CASTRO, Edgardo. Introdução a Giorgio Agamben: uma arqueologia da potência. Belo Horizonte : Autêntica Editora, 2012.

DESCARTES, René. Meditações. In: Col. Os Pensadores, volume Descartes. São Paulo: Abril Cultural, 1973.

DUARTE, André. Vidas em Risco: crítica do presente em Heidegger, Arendt e Foucault. Rio de Janeiro : Forense Universitária, 2010.

FAUSTO, Juliana. Poesia Versus Filosofia: Agamben e a 'palavra despedaçada'. Dissertação de mestrado apresentada ao Departamento de Letras da PUC-RJ em 2012.

HEIDEGGER, Martin. Ser e Tempo. Campinas: Editora da Unicamp; Petrópolis: Editora Vozes. 2012.

NIETZSCHE, Friedrich W. A Gaia Ciência. São Paulo : Companhia das Letras, 2001.

VALENTIM, Marco A. "A outra interpretação": sobre os limites de um conceito filosófico de poesia. In: FÉLIX W.; OLIVEIRA, R.; PERIUS, C. (orgs.) VI Simpósio de Filosofia da UEM - Estética: Ontem e Hoje, 2012, Maringá. Estética: Ontem e Hoje - Anais do VI Simpósio de Filosofia da UEM. Maringá: Departamento de Filosofia da Universidade Estadual de Maringá, 2012. 